\title{
Penataan Kembali Kompleks Museum Radya Pustaka Dengan Pendekatan Arsitektur Kontekstual Di SURAKARTA
}

\author{
Irma Lovita, Dwi Hedi Heriyanto, Maya Andria Nirawati \\ Program Studi Arsitektur \\ Fakultas Teknik \\ Universitas Sebelas Maret Surakarta \\ Email : irma_lovita@yahoo.com
}

\begin{abstract}
Radya Pustaka Museum Complex Realignment using Contextual Architecture approach in Surakarta caused by the rapid urban development results in the decrease of the heritage buildings image, especially in Surakarta. Radya Pustaka Museum realignment is an attempt to preserve Radya Pustaka Museum's existence as one of the oldest museums in Indonesia which preserves Javanese cultural existence proofs in the past. The realignment of the museum complex is conducted by maintaining the shape of Radya Pustaka Museum original building as a conservation effort in which the new object design functions as a new cultural appreciation place done by restoring and developing the function of previous existing activities which were able to accommodate all the museum's activities and needs. The method used is architecture designing plan method approached by Contextual Architecture. Contextual Architecture is applied as an execution design method with the purpose of creating contextual environment visual harmony between the new building and it previous environment. By using this approach, the form, mass order, and façade elements in the new building are designed by not only aesthetic and contrast appearance, but also contextual to the old one. The realignment is designed in line with Surakarta City Government Planning related to tourism, education, and culture development which are expected to make Radya Pustaka Museum as one of the main representation of the historical aspect of the city and to enact the tourism in the city of Surakarta, as the City of Culture. Also it is expected to improve the quality of life for people both inside and outside the scope of Radya Pustaka Museum complex on an ongoing basis.
\end{abstract}

Keywords: Contextual Architecture, Radya Pustaka Museum, Realignment.

\section{PENDAHULUAN}

Perkembangan pembangunan perkotaan yang kian meningkat berdampak pada munculnya kesenjangan pada wajah arsitektural kota. Menurut Lynch, 1960, sebuah kota yang hebat adalah sebuah tempat romantis yang memiliki banyak cerita, karena image sebuah kota sendiri itu tercipta dari hasil proses dua arah antara objek dan pengamat yang membentuk satu habitat tertentu dalam memori keseharian. Keberadaan bangunan cagar budaya tergeser dengan adanya bangunan komersil seperti hotel, pusat perbelanjaan, dan ruko. Visi Kota Surakarta sebagai Solo Eco Cultural City kepedulian terhadap bangunan cagar budaya diwujudkan dengan diupayakannya revitalisasi dan konservasi aset-aset cagar budaya.

Museum Radya Pustaka terletak di pusat Kota Surakarta tepatnya di Jalan Slamet
Riyadi yang mana masih termasuk dalam kawasan Taman Wisata Budaya Sriwedari sebagai salah satu aset kebanggaan Kota Surakarta dalam menunjang sektor pariwisata dan budaya. Museum yang pada tahun ini genap berusia 125 tahun adalah salah satu saksi sejarah perkembangan kebudayaan masyarakat Jawa di masa lampau. Museum yang dulunya merupakan sebuah bangunan rumah tinggal seorang Belanda ini kemudian dibeli dan difungsikan sebagai museum, sehingga beberapa aspek fungsi ruang standar persyaratan museum tidak terpenuhi.

Permasalahan makro yang muncul antara lain, adanya bangunan baru yang tidak sesuai dengan wilayah pengembangan, kurangnya ruang terbuka hijau, munculnya lost space (ruang mati yang tidak dikelola), pagar luar yang menutupi kegiatan dalam tapak, serta kawasan pujasera tidak tertata dengan baik. 
Monoton dan kurang menarik, adalah dua faktor dasar degradasi keberadaan Museum Radya Pustaka karena kegiatan yang ada dalam kompleks tidak terkelola dengan baik.

Penataan kembali kompleks Museum Radya Pustaka bertujuan untuk mengeksiskan kembali fungsi dan keberadaan Museum Radya Pustaka di Kota Surakarta. Pengelolaan kegiatan yang baik di kompleks Museum Radya Pustaka akan menjadi titik balik yang penting untuk prospek ke depan. Penambahan fungsi ini berdasarkan fungsi Museum Radya Pustaka yang dulu pernah ada seperti foodcorner dan giftshop serta fungsi tambahan seperti perpustakaan, ruang kursus, dan galeri temporer.

Kompleks museum baru direncanakan dengan memperhatikan aspek-aspek kontekstual antara bangunan yang sudah ada dengan lingkungan yang mengelilinginya. Arsitektur Kontekstual sebagai metode desain dengan tujuan terciptanya keselarasan visual yang kontekstual lingkungan antara bangunan baru dan lingkungan hidupnya yang lama sebagai upaya menumbuhkan minat masyarakat lokal maupun wisatawan asing untuk datang berkunjung sehingga ORB (Objek Rancang Bangun) dapat mengangkat Museum Radya Pustaka menjadi icon penting kota sehingga bangunan museum kembali hidup dan ramai kembali.

\section{METODE}

Berdasarkan konsep perencanaan dan perancangan penataan kembali kompleks Museum Radya Pustaka diselesaikan dengan pendekatan Arsitektur Kontekstual. Prinsip yang digunakan sebagai acuan adalah prinsip konteks-kontras, dengan tujuan menciptakan kompleks museum baru yang sustainable dengan perkembangan jaman, tetapi tetap memperhatikan unsur keharmonisan dengan bangunan lama yang dipertahankan keasliannya. Penerapan Arsitektur Kontekstual pada kompleks dimunculkan ke dalam dua aspek sebagai berikut.

1. Aspek Bentuk dan Tata Massa : menggunakan penataan massa bentuk $\mathrm{U}$ sebagai respon desain terhadap bangunan konservasi yang ada dengan sistem gabungan massa.

2. Aspek Tampilan Bangunan : menerapkan gaya Arsitektur Indische yang ada pada bangunan lama secara simbolik dengan penambahan aksen modern.

\section{ANALISIS}

\section{A. Analisis Peruangan}

Kebutuhan ruang kompleks museum yang baru berdasarkan ruang koleksi museum yang sudah ada pada bangunan lama serta kegiatan-kegiatan baru yang akan dimunculkan dalam kompleks sebagai daya tarik untuk pengguna kompleks Museum Radya Pustaka.

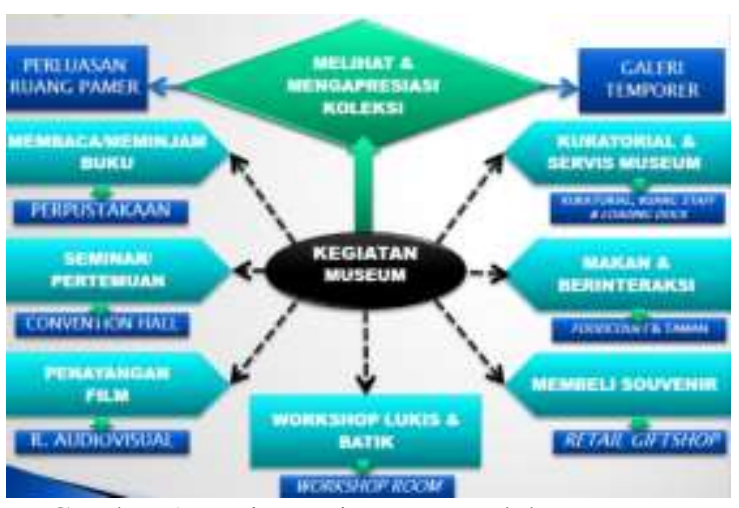

Gambar 1. Jenis Kegiatan Kompleks Museum

Pada Gambar 1. terlihat jenis kegiatan yang dikembangkan sebagai dasar pertimbangan persyaratan kebutuhan ruang.

Tabel 1.Kebutuhan Ruang

\begin{tabular}{|c|c|c|}
\hline PELAKU & KEGIATAN & PERUANGAN \\
\hline \multirow[t]{2}{*}{ Pengunjung } & $\begin{array}{l}\text { Melihat koleksi } \\
\text { museum }\end{array}$ & $\begin{array}{l}\text { R. Utama (R. } \\
\text { Penerimaan } \\
\text { Pengunjung, R. } \\
\text { Pameran, Galeri) }\end{array}$ \\
\hline & $\begin{array}{l}\text { Meminjam buku, } \\
\text { makan dan } \\
\text { membeli } \\
\text { cinderamata }\end{array}$ & $\begin{array}{l}\text { R. Penunjang } \\
\text { (Kafetaria, Gift-Shop, } \\
\text { Workshop, } \\
\text { Convention Hall, } \\
\text { Perpustakaan) }\end{array}$ \\
\hline \multirow[t]{3}{*}{ Pengelola } & Mengelola koleksi & $\begin{array}{l}\text { R. Teknis (R. } \\
\text { Penerimaan Barang, } \\
\text { R. Kuratorial, R. } \\
\text { Konservasi \& } \\
\text { Preparasi) }\end{array}$ \\
\hline & $\begin{array}{l}\text { Mengelola } \\
\text { fasilitas kompleks }\end{array}$ & $\begin{array}{l}\text { R. Administrasi (R. } \\
\text { Direktur, R. Staff, dll) }\end{array}$ \\
\hline & $\begin{array}{l}\text { Mengelola servis } \\
\text { kompleks }\end{array}$ & $\begin{array}{l}\text { R. Servis(Pantry, R. } \\
\text { Panel, Toilet, Dapur, } \\
\text { dll) }\end{array}$ \\
\hline
\end{tabular}

Pada Tabel 1. terlihat kebutuhan peruangan yang dibutuhkan dalam 
pemenuhan wadah kegiatan pada kompleks Museum Radya Pustaka.

\section{B. Analisis Lokasi}

Penentuan penggunaan tapak dilakukan melalui beberapa pertimbangan yang sangat menentukan prospek ORB.

1. Tujuan: Mendapatkan batas tapak yang sesuai dengan ORB dan mengakomodasi kegiatan dan tujuan penataan kembali kompleks Museum Radya Pustaka.

2. Dasar pertimbangan:

Bangunan Museum Radya Pustaka yang dikonservasi, posisi tapak strategis untuk ekspose tampilan fisik bangunan, luasan tapak dapat menampung seluruh kebutuhan ruang yang direncanakan, arah hadap ORB yang mendukung ekspose bangunan konservasi, adanya program rencana dari pemerintah, faktor kenyamanan standar museum, fasilitas yang sudah ada di dalam ORB.

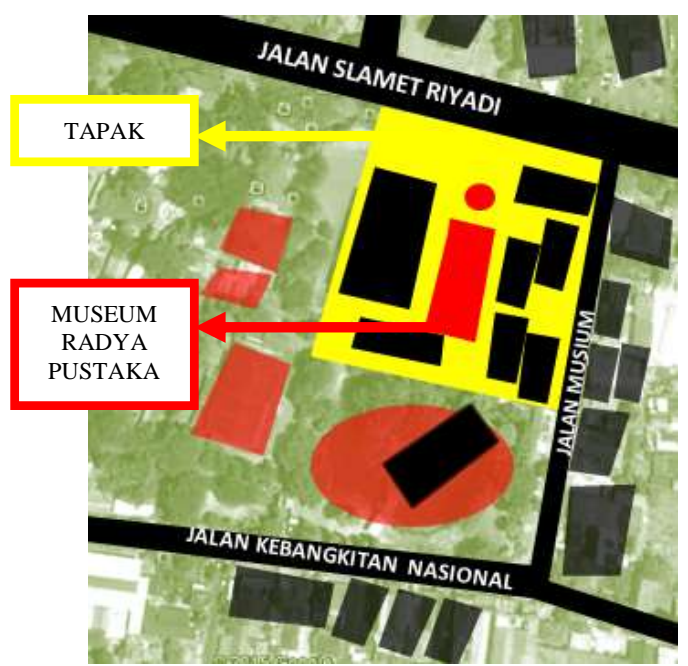

Gambar 2. Figure Ground Kompleks Museum Radya Pustaka

Pada Gambar 2. terlihat perbandingan antara batas tapak dan bangunan museum yang dikonservasi. Bangunan Kantor Dinas Pariwisata Kota Surakarta yang tidak sesuai dengan fokus pengembangan tapak dialokasikan ke daerah yang sesuai.
C. Analisis Pencapaian

Pencapaian ke dalam bangunan harus mudah diakses dan dilihat serta memiliki sirkulasi yang aman dan terpisah antara sirkulasi pengunjung, pengelola dan sirkulasi barang koleksi.

1. Tujuan: menentukan main entrane, menentukan service entrance

2. Dasar Pertimbangan: Entrance utama bangunan yang dikonservasi, kemudahan akses menghindari crossing, arus kendaraan dan potensi jalan, tingkat keamanan.

3. Proses analisis

\section{Main Entrance (ME)}

Mudah dijangkau dan terlihat dengan jelas. Menghadap langsung ke arah jalan untuk kemudahan sirkulasi kendaraan masuk dan ke luar tapak, memamerkan façade bangunan utama.

Side Entrance (SE) $\bigcirc$

Tidak mengganggu keberadaan ME. Menunjang sirkulasi pengelola dan sirkulasi barang koleksi.

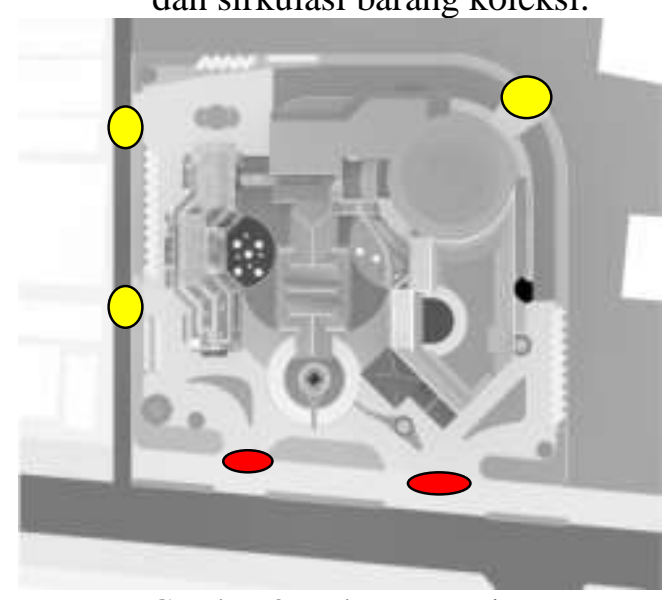

Gambar 3. Pola Pencapaian

Pada Gambar 3. menunjukkan pemisahan pola pencapaian untuk pengelola dan pengunjung.

D. Analisis Pemintakatan (Penzoningan)

Pemintakatan berdasarkan sifat kegiatan dan keadaan dalam tapak dilakukan sebagai acuan dalam penataan peruangan.

1. Tujuan: Menentukan mintakat (zoning) berdasarkan sifat kegiatan, tingkat kebisingan pada tapak, serta 
sistem pencahayaan dan penghawaan alami.

2. Dasar pertimbangan: analisis peruangan, analisis pengolahan tapak, bangunan konservasi.

3. Proses analisis: menentukan persyaratan ruang, berdasarkan kelompok kegiatan dan analisis pengolahan tapak.

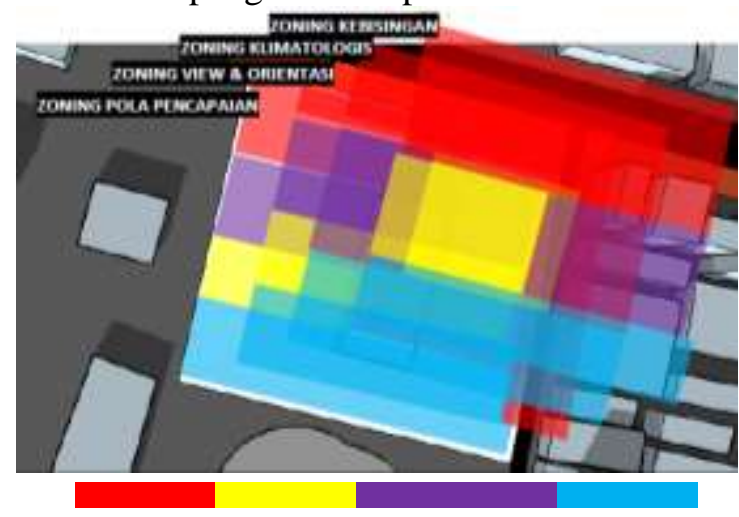

PUBLIK PRIVATE SEMI PUBLIK SERVIS Gambar 4. Pemintakan pada Tapak

Pada Gambar 4. terlihat pemintakatan dibedakan menjadi empat bagian, yaitu area publik, semi publik, privat, dan servis.

E. Analisis Bentuk dan Tata Massa

Bangunan

1. Citra pada tampilan ORB mengambil elemen-elemen gaya arsitektur yang ada pada bangunan Museum Radya Pustaka yang memiliki gaya Arsitektur Indische.

2. Penampilan Bentuk Dasar Bangunan dipertimbangkan dari bentuk gubahan segiempat dan lingkaran. Hal ini berdasarkan pertimbangan :

a. Fleksibilitas bentuk dan efisiensi penggunaan ruang.

b. Macam sifat yang diwadahi.

c. Pengkoordinasian masingmasing kegiatan.

d. Penyesuaian massa dasar terhadap fisik di lingkungan tapak dan bangunan yang sudah ada.

e. Estetika bentuk.

f. Peletakan massa yang simetris dengan bangunan konservasi sebagai sumbu utama untuk memperjelas fokus utama kompleks Museum Radya Pustaka.

g. Sistem Gabungan Massa diterapkan untuk memperoleh sirkulasi pencahayaan dan penghawaan alami optimal.

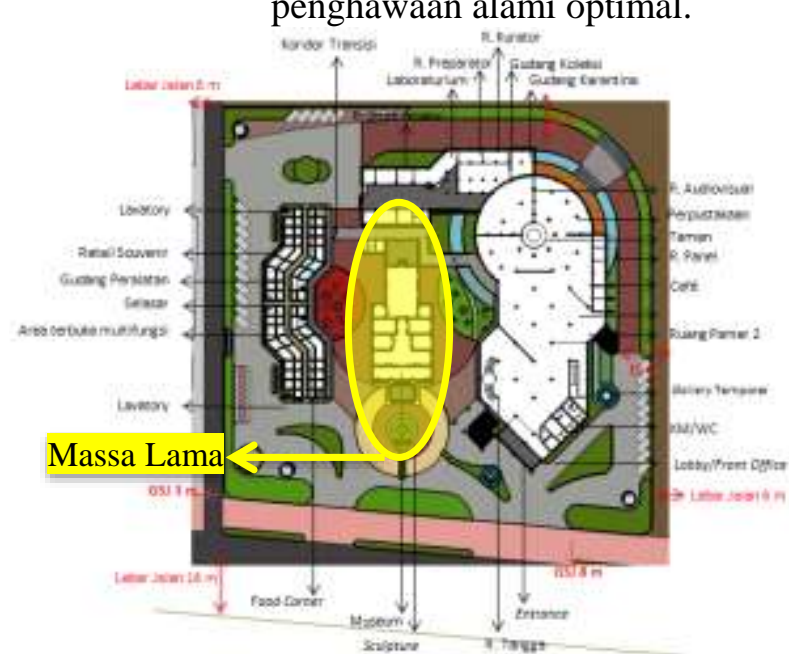

Gambar 5. Penataan Massa Dasar Bangunan

Pada Gambar 5. terlihat tata massa lantai dasar pada tapak terhadap bangunan utama museum.

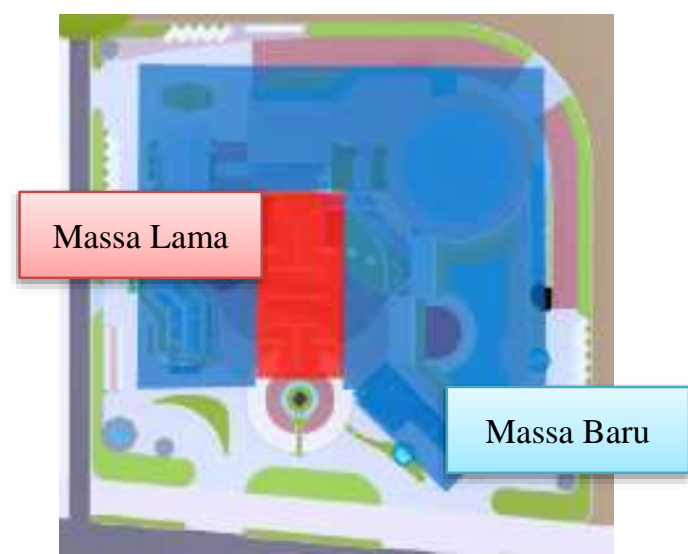

Gambar 6. Peletakan Massa Dalam Tapak Terhadap Museum

Pada Gambar 6. menunjukkan sistem peletakan massa baru bentuk $\mathrm{U}$ yang mengelilingi massa lama sebagai respon desain kontekstual.

Seluruh fasilitas yang ada pada kawasan ini akan direncanakan sesuai dengan standar rancang bangun museum, karena kompleks museum yang direncanakan ini tidak hanya sebagai pendukung aset pariwisata di Kota Surakarta namun juga sebagai 
aset peninggalan bangsa Indonesia yang berharga dari itu penyesuaian terhadap kondisi tapak perlu dilakukan sejak awal.

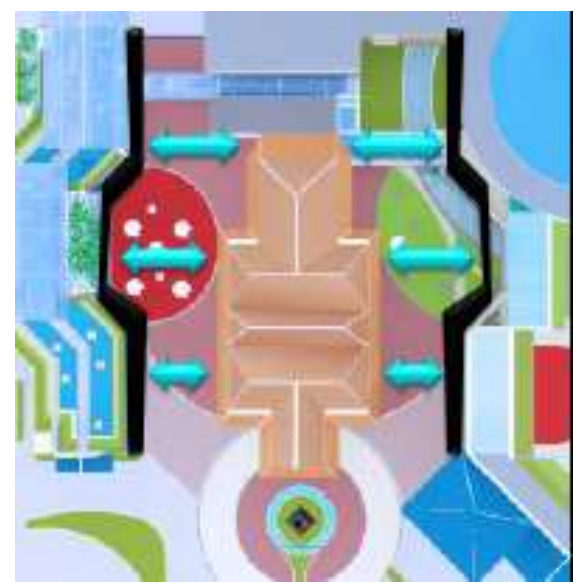

Gambar 7. Peletakan Massa Baru Terhadap Massa Lama

Pada Gambar 7. menunjukkan perbandingan antara massa lama dan massa baru yang ditempatkan pada tapak secara simetris dengan bangunan utama museum yang dikonservasi sebagai sumbu utama. Penempatan yang simetris ini bertujuan untuk menjadikan bangunan museum sebagai fokus titik pandang utama dalam kompleks.

F. Analisis Karakteristik dan Tampilan Bangunan

1. Tujuan: mendapatkan façade yang estetis dan kontekstual dengan bangunan lama.

2. Dasar pertimbangan: prinsip dasar konservasi bangunan cagar budaya, gaya arsitektural bangunan konservasi, salah satu bagian yang dapat dijadikan ekspose bangunan.

3. Proses analisis

a. Karena konsep penataan kembali yang diterapkan masih mempertahankan bentuk asli bangunan utama museum maka konsep karakteristik dan tampilan bangunan baru mengacu pada gaya arsitektural bangunan lama namun dengan desain yang lebih estetis yang mampu menarik perhatian pengunjung dan menggunakan warna-warna yang tidak monoton dengan permainan ragam tekstur material.

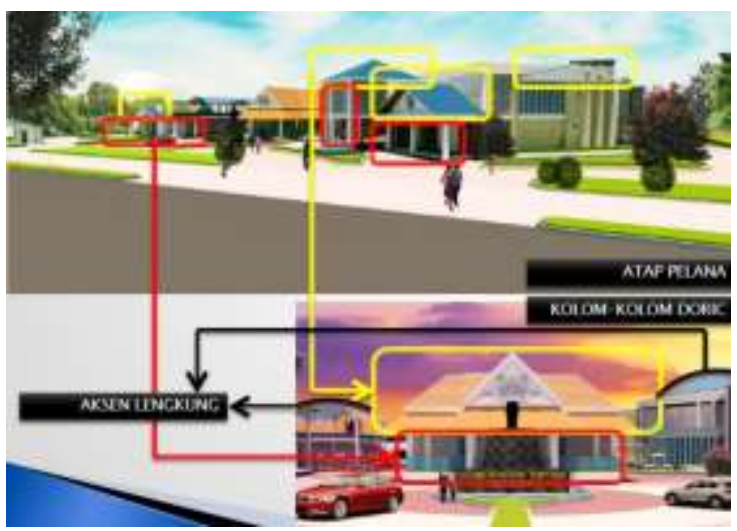

Gambar 8. Karakteristik Bangunan Lama pada Tampilan Bangunan Baru

Pada Gambar 8. terlihat gaya arsitektural bangunan baru yang kontras dan lebih modern dengan penambahan aksen gaya arsitektur bangunan lama seperti penggunaan kolom doric dan atap pelana.

b. Bangunan utama museum memiliki warna dominan putih dan coklat sehingga pada bangunan baru pemilihan warna dan tekstur material berperan penting dalam memunculkan efek kontras yang harmonis dengan visual bangunan lama.

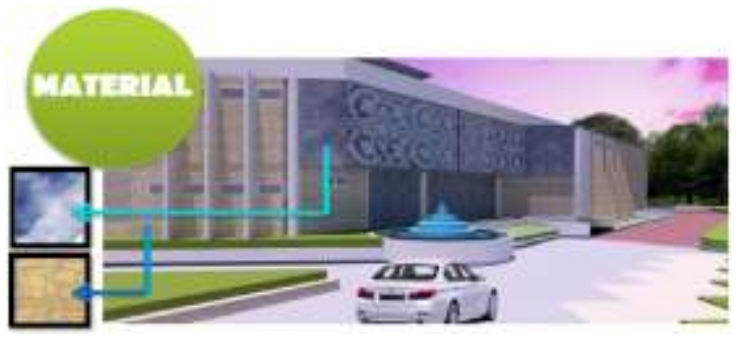

Gambar 9. Penggunaan Material pada Bangunan Baru

Pada Gambar 9. terlihat penggunaan dua material yang mendominasi bangunan baru yaitu kaca dan batu alam sebagai elemen kontras yang diterapkan. 


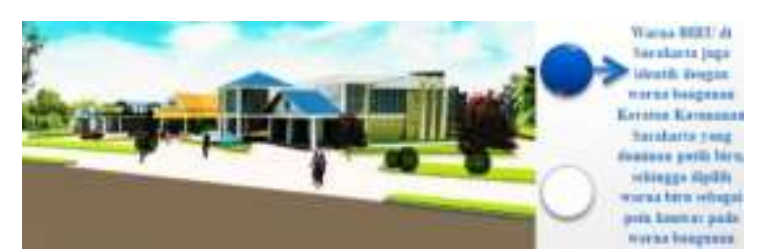

Gambar 10. Penggunaan Elemen Warna pada Bangunan Baru

Pada Gambar 10. terlihat penggunaan warna terpilih yaitu putih dan biru sebagai warna dominan pada bangunan baru. Putih dipilih sebagai warna penyelaras terhadap bangunan lama.

c. Sebagai respon desain terhadap klimatologis juga diterapkan selubung bangunan, overhang dan skylight.

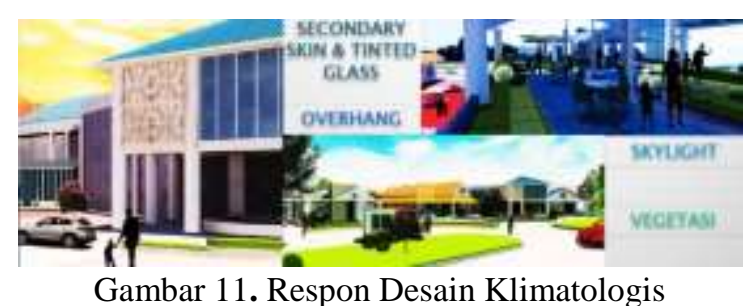

Pada Gambar 11. menunjukkan penggunaan selubung bangunan dan overhang yang juga berfungsi sebagai elemen estetis yang menarik.

G. Analisa Hardscape dan Softscape

1. Tujuan: menentukan jenis dan tata letak elemen air dan vegetasi.

2. Dasar pertimbangan: bentuk dasar tapak, luas area yang ditutupi oleh atap, kebutuhan ruang terhadap vegetasi, salah satu bagian yang dapat dijadikan ekspose bangunan.

3. Proses analisis

Menentukan jenis tanaman yang sesuai dengan kebutuhan, seperti untuk peneduh, secondary skin, penunjuk arah, dan lain-lain. Elemen pendingin yang digunakan berupa kolam ikan dan air mancur yang juga berfungsi sebagai elemen peredam kebisingan.

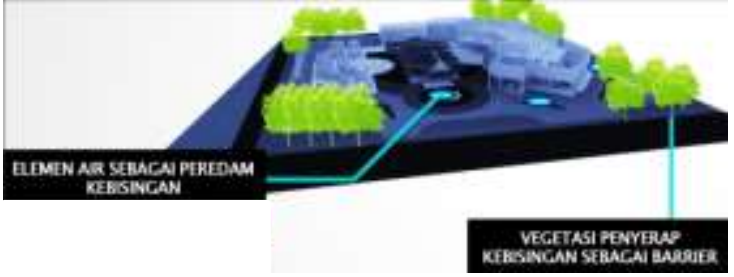

Gambar 12. Barrier Vegetasi dan Elemen Pendingin

Pada Gambar 12. terlihat peletakan elemen pendingin dan vegetasi dalam tapak yang juga berfungsi sebagai elemen estetis.

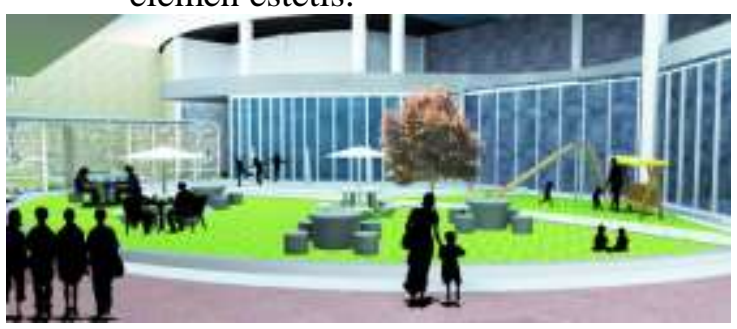

Gambar 13. Space Transisi

Pada Gambar 13. menunjukkan area transisi berupa taman air dan koridor penghubung yang menghubungkan bangunan baru dan bangunan lama.

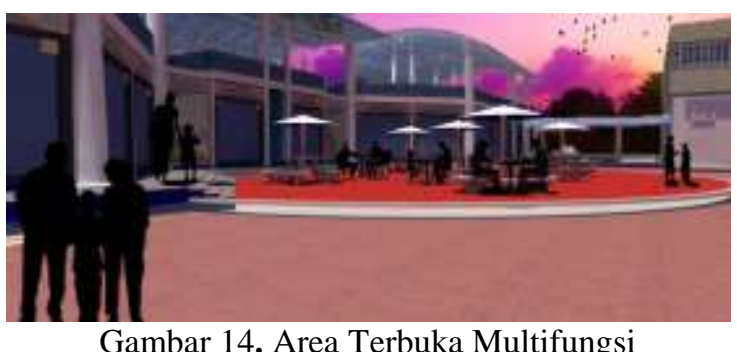

Gambar 14. Area Terbuka Multifungsi

Pada Gambar 14. terlihat area foodcourt yang dapat juga digunakan untuk acara terbuka pada event tertentu.

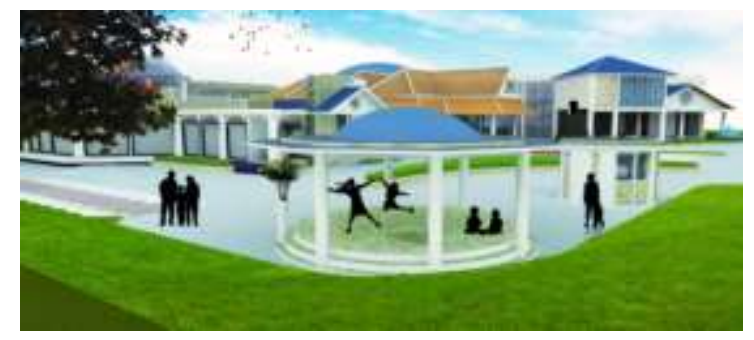

Gambar 15. Gazebo

Pada Gambar 15. terlihat peletakan gazebo sebagai elemen estetis landscape yang dapat digunakan oleh umum. 


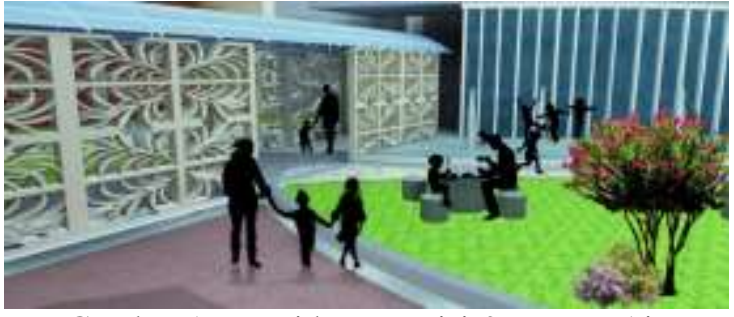

Gambar 16. Koridor Transisi \& Taman Air

Pada Gambar 16. menunjukkan elemen transparansi yang digunakan pada batas landscape dengan tujuan memberikan efek terbuka dan menyenangkan.

\section{KESIMPULAN (KONSEP DESAIN)}

Konsep rancangan penataan kembali kompleks Museum Radya Pustaka mengacu pada pendekatan Arsitektur Kontekstual.yang lebih fokus pada bentuk dan tampilan bangunan yang harmonis dengan bangunan konservasi yang sudah ada. Dari hasil analisa serta hasil korelasi dari beberapa data di atas, maka diperoleh hasil berupa rancangan penataan kembali kompleks Museum Radya Pustaka di Surakarta seperti yang terlihat pada Gambar 17. dan Lampiran 1. yang menunjukkan pengolahan façade sedangkan untuk desain tata ruang pada Gambar 18. dan Lampiran 2. dengan data ORB sebagai berikut. Nama Museum : Museum Radya Pustaka
Lokasi
: Jl. Slamet Riyadi, Surakarta

Luas Lahan

$: \pm 16.250 \mathrm{~m}^{2}$

Luas Bangunan : $\pm 5.873 \mathrm{~m}^{2}$

Daya Tampung $: \pm 3.000$ orang

Kegiatan : Ruang Apresiasi Seni dan Budaya

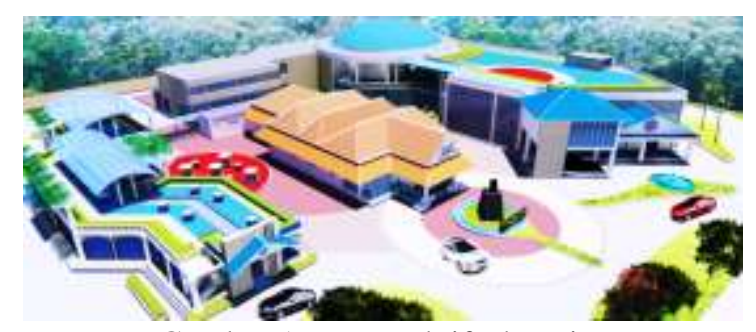

Gambar 17. Perspektif Eksterior

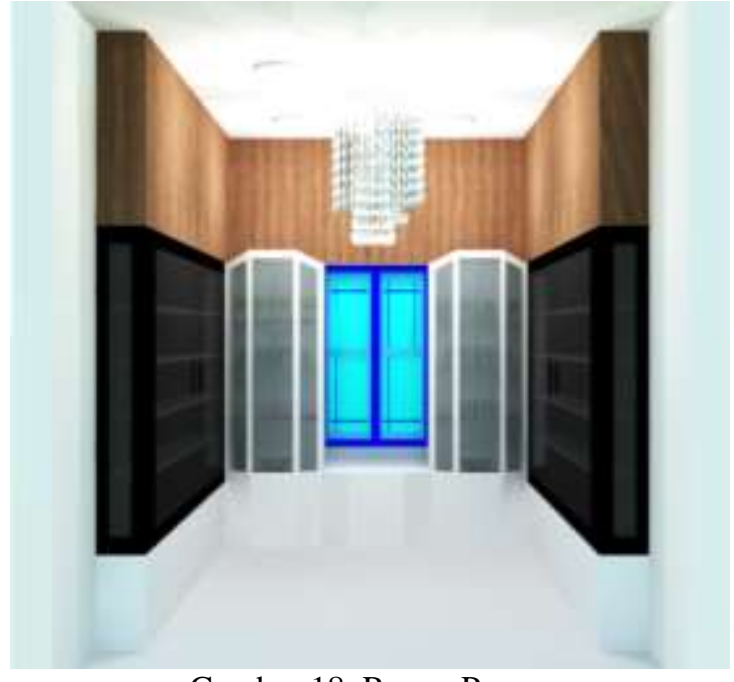

Gambar 18. Ruang Pamer

\section{REFERENSI}

Lynch, Kevin. 1960. The Image Of The City. Usa: The M.I.T. Press

www.wikimapia.com 


\section{LAMPIRAN}

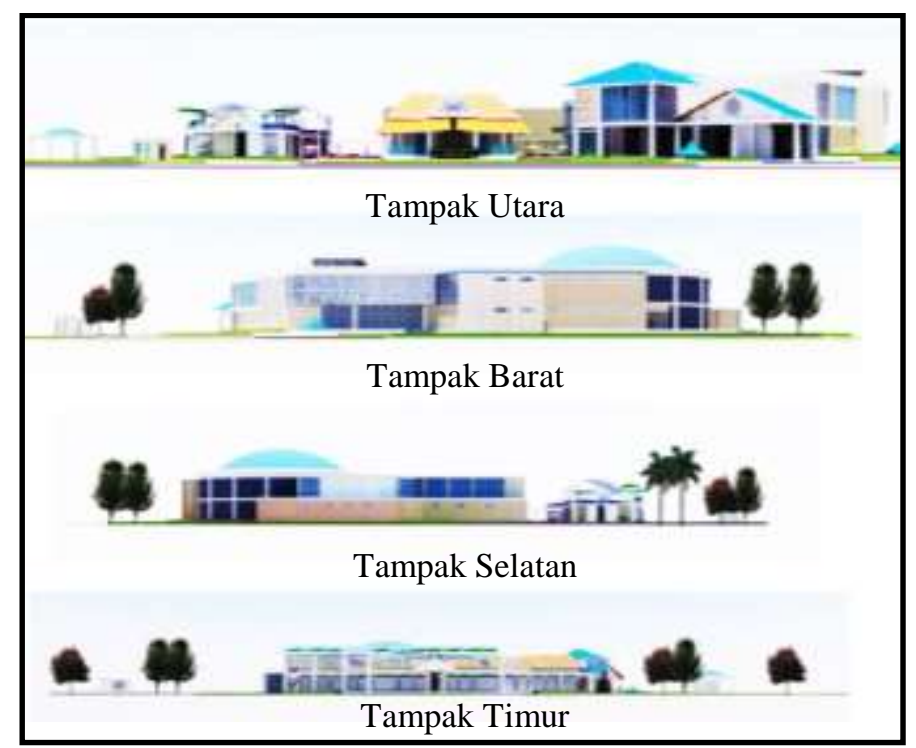

Lampiran 1. Tampak Kompleks Museum Radya Pustaka

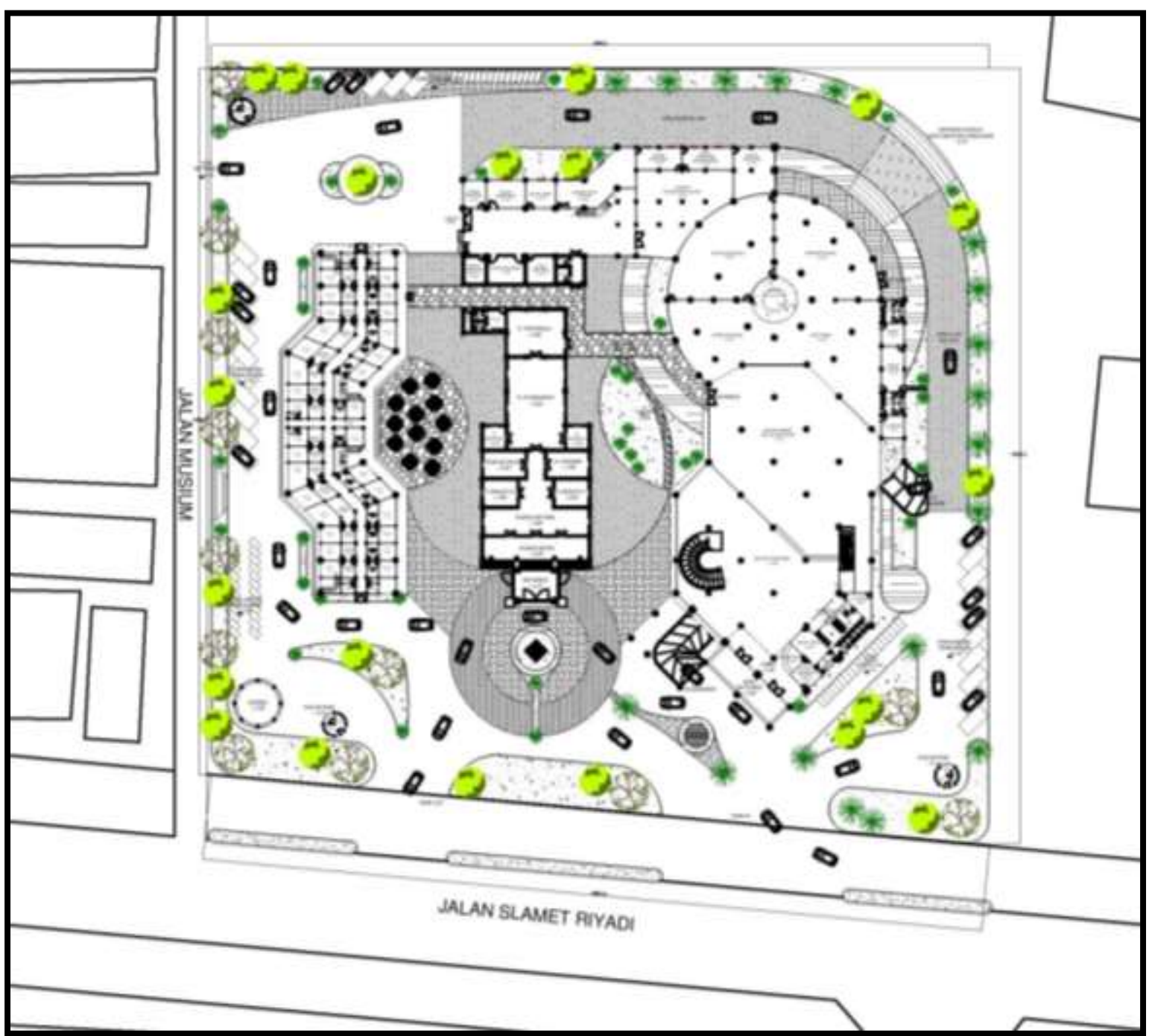

Lampiran 2. Rencana Tapak 